\title{
Local Wisdom-Based Multicultural Education: Muhammadiyah Experience
}

\author{
Abdul Mu'ti ${ }^{1}$, Alpha Amirrachman ${ }^{2}$ \\ \{ masmukti47@gmail.com ${ }^{1}, \underline{\text { alpha.amirrachman@untirta.ac.id }{ }^{2}}$ \} \\ ${ }^{1}$ Syarif Hidayatullah State Islamic University \\ ${ }^{2}$ Sultan Ageng Tirtayasa University
}

\begin{abstract}
In various cases, local wisdom plays role in helping face every day's challenges. In Indonesia's context, the society is a multicultural society and it has a variety of local wisdom. Local wisdom is a product of thoughts, views of life, behavior, habits, and other products produced by certain communities that show the identity and uniqueness of that community. The diversity of local wisdom can be developed through education because education is a place for the nation's generation to be educated and guided to become qualified individuals. Through its network of members spread across various parts of the country, Muhammadiyah has established a large number of educational institutions from early childhood to tertiary institutions spread across the archipelago. The motivation is the da'wah of Islam through educational institutions. Muhammadiyah carries the spirit of inclusivity as it has organized education for all. It can be said that Muhammadiyah adjusts itself to the local wisdom by accepting students regardless of religious, ethnic, citizenship and economic background. This inclusivity of Muhammadiyah educational institutions is proven by the fact that many Muhammadiyah schools and universities in the Eastern parts of Indonesia are attended by mostly Christian students. All in all, teachers play most important role to make sure that this democratic, peaceful and enriching school eco-system is coming into existence. The training of school staff can be perceived as emphasizing on three major parts: awareness, knowledge, and skills.
\end{abstract}

Keywords: local wisdom, multicultural education, inclusivity, teachers

\section{Introduction}

This paper explores the importance of local wisdom is fostering peace through education and to cultivate awareness among students of their both national and local identity. Later it elaborates the role Muhammadiyah as Indonesia's Muslim modernist organization in establishing and running numerous educational institutions throughout the archipelago and how the organization adopts local wisdom by being inclusive thorough the acceptance of students regardless of religious, ethnic, citizenship and economic background. The paper analyses the research finding of how non-Muslim students have chosen Muhammadiyah school as well as their parents' perception and discusses the nature of multicultural education in putting an emphasis in human relations in all its forms and the incorporation of positive social contributions of ethic and cultural groups while at the same time emphasizing on students' achievement and the reduction of religious tensions in the classroom. Finally, the paper elaborates the importance of the role of teachers in making sure that this democratic, peaceful and enriching school eco-system is coming into existence and the role of teacher training in instilling awareness, knowledge and skills among teachers. 


\section{Local wisdom in education}

Culture is a form of self-expression, which creates communal identity from which local wisdom come to take a central part in the cultural life of a community. In various cases, local wisdom plays role in helping face every day's challenges. In this case, local wisdom can be identified across various sections of human expressions such as social patterns, perceptions and lifestyle [1]. According to Geertz (in Pesurney],"local wisdom is a traditional culture element that is related to human resources, source of culture, economic, security and laws. local wisdom can be viewed as a tradition that related to farming activities, livestock, build house etc." ".

In Indonesia's context, the society is multicultural as it has a variety of local wisdom. Local wisdom is a product of thoughts, views of life, behavior, habits, and other products produced by certain communities that show the identity and uniqueness of that community. For example, in the province of Maluku, the local wisdom is known as pela-gandong. Pela-gandong relation still can be found and is customary is various villages on the islands of Ambon Haruku, Saparua, Nusalaut and Seram, peacefully connecting Muslim and Christian villages [2]. In Wajo, South Sulawesi, the value of adek pangadereng encourages the people to respect law, human rights and democratic institutions [3].

The diversity of local wisdom can further be developed through education because education is a place for the nation's generation to be educated and guided to become qualified individuals with awareness of both national and local identity. With the internalization of local wisdom, it is hoped that students can realize and understand the local wisdom of the archipelago. With the internalization of local wisdom as well, the identity of education in Indonesia can be created because the local wisdom is the basis for the development and implementation of learning [4]. The potential of local wisdom in fostering peace through education should be given special attention by the government so that learners would be familiar with their own local area and understand well about their own local wisdom [5].

The role of education in fostering multicultural society is important because classrooms can be perceived as miniature of 'real' society. 'Real' here refers to societies outside school where members of the school are from. In this case, classrooms can provide flawless environment where accepted and good values transferred and adopted. Hence, the celebrated values would be further disseminated by members of the classrooms to the wider public once they return to their society [6].

According to Prihartini to maximize positive interactions among members of the school, real efforts are needed in education to develop education that has an identity based on local wisdom and also develops education that is globally oriented [4]. The education system contributes to forging local and global aspects by increasing knowledge, skills, and values that encourage students to identify, understand, and realize, and commit to applying these local and global aspects. The National Education System Law also mentions the importance of local wisdom in collaboration with the needs of the national and global context in national education

In Indonesia, the importance of local wisdom in education is stated in the National Education System Law (UU Sisdiknas) No. 20 of 2003 concerning the management of education which reads: District/City Governments manage basic education and secondary education, as well as education units based on local excellence. Based on the National Education System Law, education is processed by utilizing local advantages. Each region in Indonesia has its own advantages, one of which is local wisdom. 


\section{Muhammadiyah experience}

Muhammadiyah, established in 1912, is a modernist Islamic organization devoting itself to nurturing educational institutions. Through its network of members spread across various parts of the country, Muhammadiyah has established a large number of educational institutions from early childhood to tertiary institutions spread across various regions. The motivation is the da'wah of Islam through educational institutions [7]. With a very large number of schools and students' diverse religious backgrounds, Muhammadiyah also had to deal with a dilemmatic situation. The dilemma is between being an educational institution that follows the government, and an organization that has a missionary mission, considering that Muhammadiyah is an Islamic movement of da'wah amar ma'ruf nahi munkar which aims to build a true Islamic society. The background of Muhammadiyah's birth is closely related to various social and religious problems caused by a syncretic religious life that deviates from the teachings of the Qur'an and Hadith, the decline of Islamic education and the backwardness of Muslims, the aggressiveness of Christian/Catholic missionary activities and the penetration of European nations [8].

What Muhammadiyah has done so far is more in the process of cultural Islamization, not the formalization of Islam. Muhammadiyah was a movement for the re-Islamization of Javanese Islamic society. That is, Muhammadiyah's da'wah wants to make an Islamic society, rather than aspires to formally establish a sharia state [9]. Muhammadiyah realizes that Indonesia is a multicultural and multireligious country. For centuries, the Indonesian people, consisting of hundreds of tribes and ethnicities, ${ }^{1}$ coexisted peacefully. The Indonesian people are very religious and obedient in carrying out their religious teachings (Hassan 2006). However, Indonesia is not a religious state (non-theocratic state). The Indonesian state is based on Pancasila which is extracted from the traditional values of the Indonesian nation. Pancasila - to borrow Abdullahi An-Naim's term-is the "Golden Rule" (Basic Rule) which has universal values across cultures, religions and human rights [10]. Existence of Pancasila is accepted by

\footnotetext{
1 Based on the 2000 Population Census, in Indonesia there are 101 ethnic groups that have their own subethnics. The total number of ethnicities and sub-ethnics is more than 1000. The largest ethnic compositions with more than one million are Javanese $(83.865,724)$, Sundanese $(30,978,404)$, Malay $(6,946,040)$, Madurese (6,771,727), Batak (6,076 .440), Minangkabau (5,475,145), Betawi (5,041,688), Bugis $(5,010,421)$, Banten (4,113,162), Banjar (3,496,273), Bali (3,027,525), Sasak (2,611. 059), Cirebon $(1,890,102)$, Chinese $(1,738,936)$, see Arifin, E. N. and A. Ananta (2003). Penduduk Indonesia: Etnis dan agama dalam perubahan politik (Indonesia's Population: Ethnicity and religion in political changes). Jakarta, LP3ES
} 
the majority of religious people ${ }^{2}$ because it provides an umbrella for plurality and freedom for every citizen to worship according to their beliefs. ${ }^{3}$

Through the natural process of accommodation, acculturation and assimilation, religious and cultural plurality forms a tolerant and open national character. The majority of the Indonesian population is Muslim, but the 'cultural trade marks' are Hindu and Buddhist heritages such as Borobudur and Prambanan temples, etc. The strong link between religion and culture makes religions in Indonesia-including Islam-tend to be syncretic [11]. Sociologically, syncretism does not always have a negative meaning. Pesantren as an educational institution that is uniquely Indonesian is a product of Javanese-Islamic syncretism. Javanese influence in Islam is also seen in religious celebrations, mosque architecture, etc. ${ }^{4}$

Muhammadiyah also carries the spirit of inclusivity as it has organized education for all. It can be said that Muhammadiyah adjusts itself to the local wisdom by accepting students regardless of religious, ethnic, citizenship and economic background. This is line with Hermawan's argument that one of the important values that needs to be cultivated and transferred to students as members of the classroom society is an awareness of the understanding of pluralism [6]. This is because of the fact that our societies are made up of various ethnic and religious groups. This awareness is proven by not thinking and believing that we are the one and only privileged group and by recognizing the possibility that other groups maybe right about things in question and could hold alternative truths. In this case, having an awareness of plurality and the idea of pluralism should prevent us from becoming a regime of truth that downplays or denies the existence of other groups that are different from us without valid reasons. Students need to essentially experience, recognize, live and hold dearly the value of pluralism. Indonesia

2 In the Congress in Semarang in 1984, Nahdlatul Ulama accepted Pancasila as the principle of the organization. A year later, 1985, through the 41st Congress held in Surakarta, Muhammadiyah accepted Pancasila as the principle of the organization and change the original purpose of the organization "to create an Islamic society" into: "to form a major, just and prosperous society that is blessed by Allah SWT." Muhammadiyah's acceptance of Pancasila took a very long time and theological debates that affected the exit of the "puritan" group from Muhammadiyah, see Harun, L. (1989). Muhammadiyah dan Azas Pancasila (Muhammadiyah and Pancasila Ideology). Jakarta, Pustaka Panjimas.

. At the 44th Congress in Jakarta, Muhammadiyah again included 'Islam' as the organizational principle. However, as stated by the General Chairperson of PP. Muhammadiyah, M. Din Syamsuddin, in his iftitah speech at the Muhammadiyah Tanwir, 25 April 2007, in Yogyakarta, Muhammadiyah remains firm in supporting Pancasila as the state's foundation.

3 In the 1945 Constitution, article 29 states: (1) The State is based on the Supreme Deity; (2) The State guarantees the independence of every resident to embrace their respective religions and to worship according to their religion and beliefs.

${ }^{4}$ In the context of Muhammadiyah, attitudes towards local culture are an interesting discourse. Internal debate

Muhammadiyah regarding culture shows the occurrence of a dynamic plurality of thoughts throughout history. This plurality of thought causes differences in da'wah strategies and organizational movements between "puritan" groups and "cultural" groups and gives birth to several variants within Muhammadiyah, please see Mulkhan, A. M. (2000). Islam murni dalam masyarakat petani (Pure Islam in rural society). Yogyakarta, Yayasan Bentang Budaya.

, Chamim, A. I. (2003). Purifikasi dan reproduksi budaya di Pantai Utara Jawa (Purification and reproduction of culture in Northern Shore of Java). Surakarta, PSB-PS UMS. 
has seen social upheavals that have been encouraged by the arrogance of a particular groups over others and this should serve as a lesson that the value of pluralism needs to be deeply cultivated in school environment. As such teachers are expected to share the idea of pluralism and transfer this value to students.

Muhammadiyah schools carry three functions: education, Islamic da'wah amar ma'ruf nahi munkar and cadre. This can be seen in the vision and mission of the Elementary and Secondary Education Council (Dikdasmen) as an assembly that is specifically devoted to the organization of Muhammadiyah education. The vision of the Council of Dikdasmen is to organize effective management and educational networks as an advanced, professional and modern Islamic movement and to lay a solid foundation for improving the quality of Muhammadiyah education. The missions of the Educational Education Council are: (a) to uphold the pure belief in monotheism; (b) disseminating Islamic teachings that are sourced from the Qur'an and Sunnah. (c) realizing Islamic charity in personal, family and community life; (d) making Muhammadiyah educational institutions a center for education, da'wah and cadre. Based on this context, Muhammadiyah has an experience in helping disseminate the value of pluralism towards Indonesia's plural society. ${ }^{5}$

This inclusivity of Muhammadiyah educational institutions is proven by the fact that many Muhammadiyah schools and universities in the Eastern parts of Indonesia are attended by mostly Christian students. In this case, Muhammadiyah carefully adopts local wisdom in running its education institutions. According to Mu'ti and Ul Haq there are aspects that can be learned from this [12]. First, religious pluralism in the life of our nation is not only based on hard facts in the form of a diversity of cultural systems, but has also been strengthened by a socio-educational system that is oriented towards civil society education. By opening up to nonMuslim students, Muhammadiyah schools have more or less embodied the spirit of civic education ${ }^{6}$ shown through the dissemination and institutionalization of democratic culture into educational institutions.

Second, from an academic perspective, the experience of a Muhammadiyah school in Nusa Tenggara Timur (NTT) that provides religious education to Catholic students suggests that there is a distinct socio-historical background that influences the pattern of interaction between Muhammadiyah followers and Christians in areas known to be predominantly nonMuslim. In this context, scholarly studies on the behavior of these puritan Muslim organizations outside Java are still very minimal, except as additional information from the grand narrative of

5 Studies on religious pluralism and multiculturalism have begun to receive attention since political reforms were marked by the development of democracy that tends to be liberal, regional autonomy, good governance, political openness and the spread of ethnic and religious nuanced violence. Although the ideas of pluralism, democracy, civil society and multiculturalism has been written and published quite a lot, research on pluralism in education is still very limited, especially those related to Muhammadiyah.

${ }^{6}$ Citizenship education itself began to be adopted and developed in Indonesia not long after the reforms rolled along with democratization demand, see Alfian (1989). Muhammadiyah: The political behaviour of a Muslim modernist orgamization under Dutch colonialism. Yogyakarta, Gadjahmada University Press and Chamim, A. I. (2001). Pendidikan kewarganegaraan: Menuju kehidupan yang demokratis dan berkeadilan. Yogyakarta, Majelis Diktilitbang PP Muhammadiyah. 
the Javanese Muhammadiyah. ${ }^{7}$ In fact, a comprehensive understanding of this movement is very important considering that Muhammadiyah has transformed into a transcultural and multiethnic movement as represented in the portrait of the plurality of students in Muhammadiyah educational institutions. ${ }^{8}$

Another example, in the interior of Kapuas Hulu several non-Muslims parents send children to SMA Muhammadiyah 1 Putussibau. Also in Ende (Flores), Christian parents send their children to SMA Muhammadiyah 1 Ende, and even Protestants teachers support the continuity of the Muhammadiyah Junior High School in Serui, Yapen Waropen by actively inviting the Protestant community to educate their children in Muhammadiyah schools.

The above phenomenon shows that Muhammadiyah as a dynamic socio-cultural phenomenon manifests itself in various expressions and even variants of religious understanding. In reality, the Islamization carried out by this movement does not always lead people to an ideal model; more modernist, rational and puritanical [13]. In fact, the process of Islamization cannot be separated from the influence of local culture in shaping the history and identity of the local community as shown by the people of Muhammadiyah Kotagede, Yogyakarta [14].

High School (SMA) is different from Madrasah Aliyah (MA). If the MA is more oriented or characterized by Islamic religious education, the high school's pressing point is to teach nonreligious (secular) sciences. It is this argument that allows the SMA Muhammadiyah Putussibau to accept non-Muslim (Dayak) students as their students. This is reinforced by the fact that Madrasah Tsanawiyah (MTs) Muhammadiyah Putussibau which is located not far from SMA Muhammadiyah has no non-Muslim students.

Although SMA Muhammadiyah carries out the mission of Islamic da'wah, the students' perceptions of this educational institution show another reality. If we look at the reasons why students, both Muslim and non-Muslim, choose Muhammadiyah High School, most of them they gave an answer because of the good quality of the school, low cost, it provides religious education according to the student's religion, and the distance between the school and the house. Such an illustration shows a tendency that non-Muslim students perceive SMA Muhammadiyah as a secular/non-religious educational institution where they can also study with Muslim students. The tendency to see Muhammadiyah schools as secular educational institutions cannot be separated from the views and reasons for non-Muslim parents to send their children to Muhammadiyah high schools. Parents of students of Dayak Taman (Protestant) and Dayak Baloh (Roman Catholic) do not mind that Muhammadiyah SMA is based on Islam. The most important thing for them is that Muhammadiyah schools can provide the best for their children. Even in their view, there is no difference between Islam and Catholicism because both teach goodness.

This is made possible due to the fact that Muhammadiyah adheres to the principle of positive pluralism. In social life, there are two types of pluralism: negative and positive pluralism. According to Kuntowijoyo, the tendency to move around, confuse or not be honest

\footnotetext{
${ }^{7}$ For example, the study on the development of the spread of the Muhammadiyah movement in the 1930s in Sumatra, Aceh, and Sulawesi, see Alfian (1989). Muhammadiyah: The political behaviour of a Muslim modernist orgamization under Dutch colonialism. Yogyakarta, Gadjahmada University Press.
}

8 The majority of students at several Muhammadiyah universities come from the NU family as seen at Malang Muhammadiyah Univeristy and in Surakarta. In Kupang, two thirds of Kupang Muhammadiyah University are non-Muslims (Protestant and Catholic). 
about religious beliefs is a form of 'negative pluralism'[15]. On the other hand, an attitude of being candid and sticking to one's beliefs and-at the same time-being receptive to and different from other people is called 'positive pluralism'. "Muhammadiyah works for the establishment of a pure Islamic creed, free from the symptoms of polytheism, heresy and superstition, without neglecting the principle of tolerance according to Islamic teachings." 9 Then the question is, what are the views and practices of positive pluralism in Muhammadiyah? By borrowing Kuntowijoyo's understanding, positive pluralism includes four aspects. First, a positive attitude towards a belief; believe in a religion, not an atheist or agnostic. Second, be positive towards other people who have different beliefs. Third, understand and accept other people with different beliefs. Fourth, providing accommodation for others in order to carry out their beliefs.

To explain the positive pluralism of Muhammadiyah, it can be studied from three perspectives. First, Muhammadiyah's view of social life. Second, the principles and basics of religion in Muhammadiyah. Third, Muhammadiyah's efforts to build unity and relations with non-Muslims. The first and second perspectives are more ideological. While the third examines historically by looking at the roles and efforts of the organization and the figures. Muhammadiyah believes that social life is sunnatullah and part of worship. In accordance with their nature, humans are social creatures. Social life is destiny, the embodiment of God's nature. ${ }^{10}$

Related to this issue, Hambali explained that social life is God's nature (provision) to give essential meaning and value to human life. No matter how perfect, individualistic humans are unable to reach the meaning and value of life [16]. Living in society has a transcendental meaning as part of worship, devotion to God Almighty.Therefore, Muhammadiyah encourages its members to be actively involved in community life. In accordance with the Islamic Living Guidelines (PHI), Muhammadiyah residents should always establish brotherhood and not be discriminatory with fellow community members. Based on Islamic morals, in neighborly life, Muhammadiyah residents should maintain rights, uphold honor and foster harmonious relations with fellow Muslims and non-Muslims [17].

Specifically, regarding neighborly relations with non-Muslims, PHI provides guidelines so that Muhammadiyah members interact naturally and be tolerant: "In neighbors of different religions are also taught to be kind and fair, they acquire rights and honor as neighbors, give halal food and can also receive food from them in the form of halal food, and maintain tolerance in accordance with the principles that taught the religion of Islam."

It can be argued that what Muhammadiyah has done is to have much broader impact of increasing cultural and religious or racial tolerance and reducing bias. According to Banks, this mode of education encompasses not only programs designed to desegregate schools, but also to improve all types of relation among societal groups such as encouraging minority teachers, antibias programs and cooperative learning programs [18]. Multicultural education puts an emphasis on human relations in all its forms and incorporate positive social contributions of

\footnotetext{
${ }^{9} \mathrm{MKCH}$ (Matan, Keyakinan, dan Clta-cita Hidup Muhammadiyah - Principle, Belief, and the Goal of Life of Muhammadiyah).

${ }^{10}$ Preamble of the Anggaran Dasar: "Living in a society is the sunnah (law of qudrat-iradat) of God for human life in this world." Personality of Muhammadiyah: "... Muhammadiyah bases all its actions and deeds on the principles summarized in the Preamble of the Articles of Association, namely: a. Human life must be based on monotheism, worship and obedience to God; b. Human life in a society... "
} 
ethnic and cultural groups, and at the same time also to enhance students achievement and reduce religious tensions within the classroom [19].

Indeed, in general, there are several perceived challenges. First, teachers still play a dominant role in almost everything including to decided what is right and wrong. In this case, teachers need to always display democratic attitude by accommodating different ideas and interpretation raised during discussion in the classroom. Second, when our students are given an opportunity to take a stand on certain issues, they tend to be unable to make their own decisions due to their perception that the 'truth' should come from their teachers and that they might receive punishment if making 'wrong' judgment. For many of them, their teacher is their sole authoritative source of truth [6].

According to Jenlink, in preparing students for their role later in a society defined by diversity - ethnic, racial, religious, gender and so on - teachers should incorporate "a quality of vision that enables teachers and students to look imaginatively at the differences of individuals, groups, and society represented by the students who enter teacher-education programs [20]. The type of vision necessary in today's diverse and multicultural societies understands that making the Other visible must necessarily involve making visible those dominant discourses in education that block teachers' and students' fuller potential with respect to understanding their work in building a democratic, multicultural society and in helping marginalized students construct empowering identities".

Therefore, as Hermawan argued, it is important to introduce students with the fact that the world is a contested arena, a site where people strive to have a say in particular matters. Students should be encouraged to search for justifiable grounds for the things that they argue for [6]. And if others have different beliefs in the matter, they should be urged to study grounds before making any judgment. Students should be trained to listen and respect what others say and believe in the matter. Simultaneously, if later they are convinced that their arguments are not justifiable, they should not hesitate to take a stand that their belief is unacceptable. Students should also be convinced that pluralism should not prevent them from sticking to their argument when their ideas are grounded and true. This is particularly the case when dealing with religion, they should be informed that they should respect the differences in and between religions. Nevertheless, they should also be taught that all regions are not the same, even though as an adherent of any religion they should also believe that their religion is the truth. When they have a debate in classroom regarding that they believe and what others believe, students must be convinced that it should be conducted in a peaceful manner.

According to Muhammadiyah experience, it can be said that teachers play utmost important role in conducting multicultural education. All in all, teachers play imperative role to make sure that this democratic, peaceful and enriching school eco-system is coming into existence. Such transformation starts with "teacher education that is multicultural and affirming of differences that define individual identity" [20]. The training of school staff can be perceived as emphasizing on three major parts: awareness, knowledge, and skills. The awareness part consists of professionals evaluating their values, myths, worldview and stereotypes. Knowledge component involves nurturing a non-stereotyping, flexible understanding of cultural, social and family dynamics of diverse groups as well as understanding of the critical socio-political, historical and economic background of the people from diverse multicultural groups. Skills consist of developing culturally sensitive, supple and empowering treatment and task strategies that come with communication skills and the incorporation of multicultural issues in the variety of treatment modalities. Such training can be held on various levels, such as formal multicultural issues coursework, in-service training and multicultural program development [21-22]. 


\section{Conclusion}

Indonesia is a multicultural society which has a rich variety of local wisdom. Local wisdom is a product of thoughts, views of life, behavior, habits, and other products produced by certain communities that show the identity and uniqueness of that community. The diversity of local wisdom should further be developed through education because education is a place for the nation's generation to be educated and guided to become qualified individuals with an awareness of both national and local identity. The potential of local wisdom in fostering peace through education should be given special attention so that learners would be familiar with their own local area and understand well about their own local wisdom. Muhammadiyah has established a large number of educational institutions from early childhood to tertiary institutions spread across various regions. Muhammadiyah realizes that Indonesia is a multicultural and multireligious country; hence, it carries the spirit of inclusivity as it has organized education for all.

It can be concluded that first, Muhammadiyah adjusts itself to the local wisdom by accepting students regardless of religious, ethnic, citizenship and economic background. This inclusivity of Muhammadiyah educational institutions is proven by the fact that many Muhammadiyah schools and universities in the Eastern parts of Indonesia are attended by mostly Christian students. Second, both Muslim and non-Muslim have chosen Muhammadiyah school because of the good quality of the school, low cost and it provides religious education according to the student's religion. It shows a phenomenon that non-Muslim students perceive Muhammadiyah school as a secular/non-religious educational institution where they can also study with Muslim students. Third, according to Muhammadiyah experience, it can also be conlcuded that teachers play an imperative role to ensure that this democratic, peaceful and enriching school eco-system is coming into existence. The training of school staff can be regarded as putting an emphasis on three major parts: awareness, knowledge, and skills. The awareness component consists of professionals evaluating their values, myths, worldview and stereotypes. Knowledge part involves nurturing a non-stereotyping, flexible understanding of cultural, social and family dynamics of diverse groups. Skills consist of developing culturally sensitive, supple and empowering treatment and task strategies.

\section{References}

[1] Pesurnay AJ. Local wisdom in a new paradigm: Applying system theory to the study of local culture in Indonesia. InIOP Conference Series: Earth and Environmental Science 2018 Jul 1 (Vol. 175, No. 1, p. 012037). IOP Publishing..

[2] Amirrachman RA. Peace education in the Moluccas, Indonesia: between global models and local interests. UvA-DARE (Digital Academic Repository)(nd). 2012.

[3] Wagiran W. Pengembangan Karakter Berbasis Kearifan Lokal Hamemayu Hayuning Bawana (Identifikasi Nilai-Nilai Karakter Berbasis Budaya). Jurnal Pendidikan Karakter. 2012(3).

[4] Prihatini, A. Kearifan lokal: Pembangunan jati diri pendidikan nusantara (Local wisdoms: The devepopment of of Nusantara education identity). Pendidikan Karakter dalam Bisnis dan Manajamen (Character Education in Business and Management), University of Mercubuana. 2017. 
[5] Darmadi H. Educational management based on local wisdom (descriptive analytical studies of culture of local wisdom in West Kalimantan). Journal of Education, Teaching and Learning. 2018 Mar 31;3(1):135-45.

[6] Hermawan, B. Disseminating an objective pluralism in the classroom. The Jakarta Post. Jakarta. 2008.

[7] Tholkhah I. Pendidikan Toleransi Keagamaan: Studi Kasus SMA Muhammadiyah Kupang Nusa Tenggara Timur. Edukasi. 2013;11(2):294591.

[8] Pasha MK, Darban A. Muhammadiyah sebagai gerakan Islam: dalam perspektif historis dan ideologis. LPPI, Universitas Muhammadiyah Yogyakarta; 2000. Yogyakarya, LPPI Universitas Muhammadiyah Yogyakarta.

[9] Nakamura, M. The crescent arises over the banyan tree: A study of the Muhammadiyah movement in a Central Javanese town, Gadjah Mada University Press. 1983.

[10] An-Na'im, A. A. Islam dan negara sekuler: Menegosiasikan masa depan syariah (translation) (Islam and secular countries: Negotiating the future of syariah). Bandung, Mizan. 2007.

[11] Azra, A. Konteks berteologi di Indonesia: Pengalaman Islam (The context of theological practice in Indonesia: The experience of Islam). Jakarta, Parmadina. 1999.

[12] Mu'ti, A. and F. R. U. Haq. Kristen Muhammadiyah: Konvergensi Muslim dan Kristen dalam pendidikan (Muhammadiyah Christians: Convergence between Muslims and Christians in education Jakarta, Al Wasat. 2009.

[13] Chamim, A. I. Purifikasi dan reproduksi budaya di Pantai Utara Jawa (Purification and reproduction of culture in Northern Shore of Java). Surakarta, PSB-PS UMS. 2003.

[14] Sulistiyanto P. Muhammadiyah, local politics and local identity in Kotagede. Sojourn: Journal of Social Issues in Southeast Asia. 2006;21(2):254-71.

[15] Kuntowijoyo. Muslim tanpa Mesjid: Esai-esai agama, budaya dan politik dalam bingkai strukturalisme transendental (Muslims without mosque: Essays on religion, culture and politics within the perspective of transcendental structuralism). Bandung, Mizan. 2001.

[16] Hambali H. Ideologi dan strategi Muhammadiyah (Ideology and strategies of Muhammadiyah). Yogyakarta, Suara Muhammadiyah. 2006.

[17] Pimpinan Pusat Muhammadiyah. Pedoman hidup Islami warga Muhammadiyah (Islamic living guidance of Muhammadiyah members). Yogyakarta, Suara Muhammadiyah. 2001.

[18] Tomlinson S. Banks, JA (1994). An introduction to multicultural education. Boston: Allyn \& Bacon. Blair, T.(1998). The Third Way: New politics for a new century. London: Fabian Society. Bullock, A.(1975). A language for life: The Bullock Report. London: Her Majesty's Stationery Office (HMSO). The Routledge International Companion to Multicultural Education.;1:132.

[19] Sleeter CE, Grant CA. Making choices for multicultural education: Five approaches to race, class and gender. Wiley; 2007.

[20] Jenlink PM. Affirming diversity, politics of recognition, and the cultural works of schools. The struggle for identity in today's schools: Cultural recognition in a time of increasing diversity. 2009 Apr 16:14-29. Littlefielf Education.

[21] Sue DW, Arredondo P, McDavis RJ. Multicultural counseling competencies and standards: A call to the profession. Journal of Counseling \& Development. 1992 Mar 4;70(4):47786.

[22] Sue DW, Bernier JE, Durran A, Feinberg L, Pedersen P, Smith EJ, Vasquez-Nuttall E. Position paper: Cross-cultural counseling competencies. The counseling psychologist. 1982 Jun;10(2):45-52. 


\section{Footnote}

Alfian. Muhammadiyah: The political behaviour of a Muslim modernist orgamization under Dutch colonialism. Yogyakarta, Gadjahmada University Press. 1989.

Arifin, EN, A Ananta. Penduduk Indonesia: Etnis dan agama dalam perubahan politik (Indonesia's Population: Ethnicity and religion in political changes). Jakarta, LP3ES. (2003)

Chamim, AI. Pendidikan kewarganegaraan: Menuju kehidupan yang demokratis dan berkeadilan. Yogyakarta, Majelis Diktilitbang PP Muhammadiyah. 2001.

Geertz C. The interpreation of cultures. New York, Basic Books, Inc. 1973

Harun L. Muhammadiyah dan Azas Pancasila (Muhammadiyah and Pancasila Ideology). Jakarta, Pustaka Panjimas. 1989.

Hassan R. Keragaman iman: Studi komparatif masyarakat Muslim (translation) (The diversity of faith: Comparative study of Muslim society). Jakarta, Raja Grafindo Persada-PPIM. 2006.

Mulkhan, AM. Islam murni dalam masyarakat petani (Pure Islam in rural society). Yogyakarta, Yayasan Bentang Budaya. 2000. 